\title{
The possibility of forming a sacrificial anode coating for $\mathrm{Mg}$
}

Guang-Ling Song, Nancy J. Dudney, Juchuan Li, Robert L. Sacci, Jeffery K. Thomson

Materials Science and Technology Division, Oak Ridge National Laboratory

One Bethel Valley Road, PO Box 2008, MS6156, Oak Ridge, TN 37830, USA

guangling.song@gmail.com, +1-865-574-4451

\section{Abstract}

$\mathrm{Mg}$ is the most active engineering metal, and is often used as a sacrificial anode/coating to protect other engineering metals from corrosion attack. So far no sacrificial anode coating has been developed or considered for $\mathrm{Mg}$. This study explores the possibility of forming a sacrificial coating for $\mathrm{Mg}$. A lithiated carbon coating and a metaphosphated coating are applied on the $\mathrm{Mg}$ surface, respectively, and their open-circuit-potentials are measured in saturated $\mathrm{Mg}(\mathrm{OH})_{2}$ solution. They exhibit more negative potentials than bare $\mathrm{Mg}$. SEM reveals that the metaphosphated coating offers more effective and uniform protection for $\mathrm{Mg}$ than the lithiated carbon coating. These preliminary results indicate that development of a sacrificial anode coating for $\mathrm{Mg}$ is indeed possible.

Keywords: A. Mg; B. corrosion potential monitoring; B. SEM; C. sacrificial anode coating 


\section{Introduction}

$\mathrm{Mg}$ is the lightest engineering metal. While the high strength/weight ratio and good castability are making $\mathrm{Mg}$ alloys irresistible candidate materials in the auto industry, the poor corrosion resistance of the alloys to a great degree limits their practical applications [1]. To improve their corrosion resistance, organic painting, metallic plating, surface alloying, surface conversion and anodization, etc. have been tried [2, 3]. However, most of the proposed or tested coatings have open-circuit potentials (OCPs) more positive than $\mathrm{Mg}$ in aqueous media. If they are damaged, which is unavoidable in practice, the corrosion of the locally exposed substrate Mg will be severely accelerated.

It is well known that galvanized steel does not suffer from serious corrosion even after the galvanizing coating is locally damaged, because the coating has an OCP more negative than the substrate steel and thus it acts as a sacrificial anode to cathodically protect the exposed steel [4]. If a sacrificial anode coating could also be developed for $\mathrm{Mg}$, its impact on $\mathrm{Mg}$ applications would be as profound as that of the galvanizing technique on steel.

Traditionally, Mg is too active to be protected by a sacrificial anode coating. Instead, it has been widely used as a key element in sacrificial anode coatings or as an anode to protect other metals $[5,6]$. The possibility of protecting $\mathrm{Mg}$ from corrosion by a sacrificial coating has never been explored, because forming a metallic sacrificial anode layer on $\mathrm{Mg}$ is extremely difficult. The standard equilibrium potential of $\mathrm{Mg}$ is as negative as $-2.644 \mathrm{~V}$ vs. the Saturated Calomel Electrode (SCE). Active metallic elements, like $\mathrm{Ca}, \mathrm{Li}, \mathrm{K}$ and $\mathrm{Na}$, may have potentials more negative than $\mathrm{Mg}$, but their self-dissolution/corrosion is too rapid. They are 
too reactive to form a stable and durable coating on $\mathrm{Mg}$ [7]. An ideal sacrificial anode should not only provide a large anodic current, but also have a negligible self-dissolution/corrosion rate. Thus, these active metallic elements cannot be directly used as sacrificial materials. Moreover, in a corrosive environment like seawater, $\mathrm{Mg}$ is already at the least noble end of the galvanic series [8]. In theory, there is no engineering metal more negative than $\mathrm{Mg}$ in potential to act as a sacrificial anode for $\mathrm{Mg}$.

Fortunately, Song et al. [9] found that when $\mathrm{Mg}$ was cathodically polarized to a potential slightly $(\sim 30 \mathrm{mV})$ more negative than its OCP (the OCP is about $1000 \mathrm{mV}$ more positive than $\mathrm{Mg}$ standard equilibrium potential), its dissolution rate became sufficiently low. There is no need for Mg to be cathodically polarized to its equilibrium potential. This significantly reduces the voltage requirement for a sacrificial anode coating on $\mathrm{Mg}$.

Recently, GM R\&D [10] proposed a lithiated graphite layer as a sacrificial anode coating for Mg. A very small amount (5 10 at.\%) of intercalated Li ions can make the potential of lithiated graphite more negative than that of $\mathrm{Mg}[11,12]$. As the intercalated Li ion is not exposed to environment directly, the coating is expected to be more stable than metallic $\mathrm{Li}$.

Another possible approach proposed to form a sacrificial anode coating for $\mathrm{Mg}$ is conversion treatment. This strategy is quite challenging, as most of the conversion films, including phosphated [13] and anodized [14] films, are nobler than Mg. However, if a conversion coating with an OCP more negative than the OCP of $\mathrm{Mg}$ can be obtained, it will be more feasible and practical than the lithiated $\mathrm{C}$ coating. 
In this study, the possibility of forming a lithiated $\mathrm{C}$ film (which has been well investigated for lithium ion batteries) and an innovative metaphosphate conversion layer as sacrificial anode coatings for $\mathrm{Mg}$ is explored.

\section{Experimental}

To eliminate the influence of alloying elements and intermetallic phases on coating formation, pure $\mathrm{Mg} \quad(\mathrm{Al}<0.01 w t . \% ; \mathrm{Cu}<w t .0 .01 \% ; \mathrm{Fe}<0.03 w t . \% ; \quad \mathrm{Mn}<0.002 w t . \%, \quad \mathrm{Ni}<0.01 w t . \%$, $\mathrm{Si}<0.01 \mathrm{wt} . \%$; $\mathrm{Zn}<0.01 \mathrm{wt} . \%$ ) was used as the substrate. $10 \mathrm{~mm} \times 10 \mathrm{~mm} \times 10 \mathrm{~mm}$ cubic coupons were cut from magnesium ingot and mounted in epoxy resin as electrodes. Their working surfaces were abraded by SiC paper until P\#1200. $\Phi 15 \mathrm{~mm} \times 3 \mathrm{~mm}$ disks were also cut from the ingot and abraded to P\#1200.

The lithiated carbon coating was formed as follows [15]: Mesophase graphite (MGP-A, Pred Materials) as carbon source was annealed under $\mathrm{Ar}(\mathrm{g})$ for $3 \mathrm{~h}$ at $500^{\circ} \mathrm{C}$. After being transferred into a pressurized Ar atmosphere glove box, the carbon source $(1 \mathrm{~g})$ and stabilized lithium metal powder (0.1 g SLMP, FMC Lithium) were mixed in a gastight high-density polyethylene (HDPE) container along with $7 \mathrm{~g}$ of dried $\mathrm{ZrO}_{2}$ milling media $(5 \mathrm{~mm}$ in diameter). The container was then placed into a stainless steel bomb, sealed, locked into a SPEX 8000M mixer/mill and shaken vigorously $(1725 \mathrm{rpm})$ for $1 \mathrm{~h}$. Such mixed powder can be $99 \%$ lithiated to $\mathrm{LiC}_{6}[15]$. In the glove box, a droplet $(\sim 0.03 \mathrm{~mL})$ of 1-methyl-2pyrrodinone (NMP) solvent was deposited on the Mg electrode or disk and spread uniformly over the whole working surface area using a dropper. A tiny amount $(\sim 8 \mathrm{mg})$ of the $\mathrm{LiC}_{6}$ 
powder was sprayed on the NMP wet surface with another dry dropper to form paste-like slurry uniformly covering the whole working surface area. After being dried in the glove box for 1 night, the $\mathrm{LiC}_{6}$ coated electrode and disk were ready for use.

To understand the effect of lithiation of graphite on coating protection performance, carbon coating (C) without intercalated lithium was also prepared by following the same procedures as for Li ion battery anodes [16]: $80 \mathrm{wt} . \%$ battery-grade graphite (C) was mixed with 10 wt.\% polyvinylidene fluoride binder (PVDF, Sigma-Aldrich) and 10 wt.\% carbon black (C65, Timcal) for $10 \mathrm{~min}$ in the SPEX 8000M mixer/mill. A proper amount of NMP solvent (roughly 3 5 mL NMP for $1 \mathrm{~g}$ of the $\mathrm{C}$ and PVDF mixed powder) was added to the milled powder in a vial, and the slurry was further mixed using a low-energy mixer for 2 hours to achieve uniform viscosity. A droplet $(\sim 0.03 \mathrm{~mL})$ of this slurry was placed on the $\mathrm{Mg}$ electrode and disk surfaces, uniformly spread over the surfaces using a dropper, and dried over night.

The metaphosphated coating is much simpler than the $\mathrm{CLi}_{6}$ and $\mathrm{C}$ coatings. The abraded $\mathrm{Mg}$ electrodes and disks were immersed in a metaphosphoric acid $\left(\mathrm{HPO}_{3}\right.$, Sigma-Aldrich) solution (200 $\mathrm{g} \mathrm{HPO}_{3}$ dissolved in $200 \mathrm{~g}$ distilled water) for 10 seconds. They were then directly immersed in $10 \mathrm{ml}$ of sodium metaphosphate $\left(\mathrm{NaPO}_{3}, \mathrm{ACROS}\right)$ solution $\left(60 \mathrm{~g} \mathrm{NaPO}_{3}\right.$ dissolved in $500 \mathrm{~g}$ distilled water) for 24 hours. After rinsing with distilled water, they were dried in air.

This is a preliminary study aiming at exploring the possibility of forming a sacrificial coating on $\mathrm{Mg}$. It is inappropriate to use a too corrosive test solution, as rapid corrosion can 
overwhelm the sacrificial behavior of a coating. Thus, saturated $\operatorname{Mg}(\mathrm{OH})_{2}$, a very mild electrolyte, was used. This test solution not only mimics the main composition of the aqueous environment that corroding Mg may be exposed to in coating-damaged areas, but also ensures a constant $\mathrm{pH}$ for better reproducibility in electrochemical and corrosion tests [17].

OCP monitoring is the simplest method to indicate if the surface film is a sacrificial anode coating for Mg. An electrolyte cell with a saturated calomel reference (SCE) electrode and a Pt foil $(25 \mathrm{~mm} \times 25 \mathrm{~mm})$ counter electrode was used. The bare or coated $\mathrm{Mg}$ electrode was immersed in the test solution in the cell. Its OCP was recorded through a potentiostat (PARSTAT 4000).

Immersion corrosion test was carried out in the same solution. Bare and coated $\mathrm{Mg}$ disks were immersed in $10 \mathrm{~mL}$ of the solution for 24 hours. The corroded disks were analyzed by scanning electron microscopy (SEM) (Hitachi model S3400 and S4800).

\section{Results and Discussion}

Figure 1 shows the OCPs of the bare and coated Mg electrodes. The C-coated sample has an OCP more positive than that of the bare $\mathrm{Mg}$ in saturated $\mathrm{Mg}(\mathrm{OH})_{2}$, because $\mathrm{C}$ is an inert electrode and its OCP is determined by the redox reaction of the basic water, which has a more positive OCP than Mg. After the coating degrades and the substrate $\mathrm{Mg}$ is exposed in later stages, due to the galvanic effect of $\mathrm{Mg}$, the OCP shifts negatively. Such a coating is cathodic to the substrate $\mathrm{Mg}$ and it can accelerate the substrate corrosion after damage. Lithiation of $\mathrm{C}$ significantly shifts the OCP to a value more negative than that of the bare Mg. This suggests 
that the $\mathrm{LiC}_{6}$ layer is anodic to the substrate $\mathrm{Mg}$ and may act as a sacrificial anode coating for $\mathrm{Mg}$ as proposed [10]. However, the potential gradually becomes more positive with immersion time, indicating that the coating may lose its protective effect after the lithium ions are exhausted. This is actually a common problem that all the sacrificial coatings have; the protective effect decreases as sacrificial materials are consumed, and the coatings eventually lose their sacrificial protection performance after their sacrificial materials are exhausted.

The most important finding is that the metaphosphated $\mathrm{Mg}$ exhibits an OCP more negative than that of the bare $\mathrm{Mg}$, meaning that the coating is also anodic to $\mathrm{Mg}$. Such a negative potential of a conversion coating on $\mathrm{Mg}$ has never been reported before. Its OCP being more negative than that of the $\mathrm{LiC}_{6}$ coating suggests that it may offer better protection for $\mathrm{Mg}$ than the $\mathrm{LiC}_{6}$.

To verify the protection performance of these coatings as predicted by the above OCP measurements, bare and coated $\mathrm{Mg}$ disks after 1 day immersion in saturated $\mathrm{Mg}(\mathrm{OH})_{2}$ were examined under SEM (Fig. 2). The corrosion product layer on the bare Mg (Fig. 2a) is $\sim 3 \mu \mathrm{m}$ thick and has many micro-cracks; at some points, corrosion penetrates $\sim 5 \mu \mathrm{m}$ deep. The corrosion product layer under the C-coating (Fig. 2b) is $30 \sim 40 \mu \mathrm{m}$ thick. The layer is not uniform with many micro-cracks (insert in Fig. 2b). The deeper corrosion damage confirms the OCP prediction (Fig. 1) that the C-coating accelerates the corrosion of $\mathrm{Mg}$. On the $\mathrm{CLi}_{6^{-}}$ coated $\mathrm{Mg}$ (Fig. 2c), the corrosion depth in the uniformly corroded areas is $\sim 2 \mu \mathrm{m}$, slightly less than that of the bare $\mathrm{Mg}$ (Fig. 2a). There are also a few deep corrosion-penetrations on the $\mathrm{CLi}_{6}$-coated $\mathrm{Mg}$ (Fig. 2c). Some of them are relatively deep, but the number of these deep 
penetrations (Fig. 2c) is lower than those on the bare Mg (Fig. 2a). Even in the deeply corroded areas (insert in Fig. 2c), the penetration depth is smaller than that of the C-coated $\mathrm{Mg}$ (Fig. 2b). This demonstrates the beneficial effect of the intercalated $\mathrm{Li}$ in the C-coating on the protection performance as suggested by the OCP measurement (Fig.1). The surface film on the metaphosphated $\mathrm{Mg}$ (Fig. 2d) is more discontinuous than the others. Its total thickness is $\sim 10$ $\mu \mathrm{m}$. If examined carefully, this film is formed of two distinct layers (insert in Fig. 2d); the inner layer is more continuous but thinner than the outer layer.

To clarify the layer formation mechanism, EDS elemental mapping of the metaphosphated $\mathrm{Mg}$ before and after immersion test was carried out (Figs. 3 and 4), respectively. Before immersion, the metaphosphated coating does not have two distinct layers (Fig. 3a). It has thickness and discontinuity features similar to the outer layer after corrosion (Fig. 2d), which mainly contains $\mathrm{P}$ and $\mathrm{O}$, but no $\mathrm{Mg}$ (see EDS $\mathrm{P}, \mathrm{O}$ and $\mathrm{Mg}$ maps in Fig. 3b), suggesting that the layer is a metaphosphate compound. Therefore, the outer layer should be the original metaphosphated film. After immersion in the test solution for 24 hours, the relatively thin and continuous inner layer emerges (Fig. 2d and Fig.4a). EDS elemental mapping (Fig. 4b) shows that the inner layer contains $\mathrm{O}$ and partially $\mathrm{P}$ and $\mathrm{Mg} ; \mathrm{Mg}$ concentration gradually increases with depth, while $\mathrm{P}$ distribution is limited in the utmost top zone. The outer layer has similar chemical composition (see $\mathrm{P}$ and $\mathrm{O}$ maps in Fig. 4b) as that before corrosion (see $\mathrm{O}$ and $\mathrm{P}$ maps in Fig. 3). All these results suggest that the inner layer is a corrosion product film. Some P may be dissolved from the outer metaphosphated coating and deposited on the surface of the corrosion product film, resulting in a $\mathrm{P}$ contaminated utmost top zone in the inner layer. From the insert image in Fig.2d, the corrosion depth (i.e., the inner layer thickness) can be measured 
to be $\sim 2 \mu \mathrm{m}$, shallower than the corrosion penetration on bare $\mathrm{Mg}$ (Fig. 2a). It is uniform and there is not deeply penetrated area. These observations mean that the metaphosphated coating offers good protection for $\mathrm{Mg}$, and support the evidence from the OCP measurement that the metaphosphated layer is a more effective sacrificial anode coating on $\mathrm{Mg}$ than the lithiated graphite.

Why the metaphosphated layer has a potential more negative than $\mathrm{Mg}$ is unclear in this preliminary study, and requires further investigation. Nevertheless, the finding signifies that some conversion coatings could become innovative sacrificial anode coatings for $\mathrm{Mg}$, which may open up a new field and approach in $\mathrm{Mg}$ research and applications.

\section{Concluding Remarks}

The lithiated $\mathrm{C}$ and metaphoshated coatings exhibit a sacrificial anode coating behavior on $\mathrm{Mg}$ in saturated $\mathrm{Mg}(\mathrm{OH})_{2}$. Nevertheless, this does not mean they can effectively protect $\mathrm{Mg}$ in a very corrosive environment, as the sacrificial protection effect is not strong enough for many practical applications yet. The search for more these kinds of coatings with better sacrificial performance for $\mathrm{Mg}$ will be an interesting scientific topic.

\section{Acknowledgements}

The Research was sponsored by the Laboratory Directed Research and Development Program of Oak Ridge National Laboratory. The graphite materials were kindly supplied by Pred Materials. The authors would like to thank GM R\&D director, Dr. M.W.Verbrugge, for his 
support and beneficial discussion in this project. Also, T. Lowe's help in SEM experiment is highly appreciated.

This manuscript has been authored by UT-Battelle, LLC, under Contract No. DE-AC0500OR22725 with the U.S. Department of Energy. The United States Government retains and the publisher, by accepting the article for publication, acknowledges that the United States Government retains a non-exclusive, paid-up, irrevocable, world-wide license to publish or reproduce the published form of this manuscript, or allow others to do so, for United States Government purposes.

\section{References}

1. B.A.Shaw, Corrosion Resistance of Magnesium Alloys, ASM Handbook, Volume 13A Corrosion: Fundamentals, Testing, and Protection, 2003 ASM International, p692-696.

2. G.-L.Song (ed.), Corrosion of Mg Alloys, WP publisher, 2011.

3. G.-L.Song (ed.), Corrosion Prevention of Mg Alloys, WP publisher, 2013.

4. C.R. Shastry, Corrosion of Metallic Coated Steels, Corrosion: Materials, Vol. 13B, ASM Handbook, ASM International, 2005, p 35-39

5. A. M. Simoes, D. Battocchi, D. E. Tallman, G. P. Bierwagen, SVET and SECM imaging of cathodic protection of aluminium by a Mg-rich coating, Corrosion Science 49(2007)38383849.

6. B. Yu, J. Uan, Sacrificial Mg film anode for cathodic protection of die cast Mg-9wt.\%Al1wt.\%Zn alloy in $\mathrm{NaCl}$ aqueous solution, Scripta Materialia 54(2006)1253-1257. 
7. W. M. Haynes (ed.), CRC Handbook of Chemistry and Physics, 92nd Edition, National Institute of Standards and Technology, Internet Version 2012.

8. R. Baboian, Galvanic Corrosion, Corrosion: Fundamentals, Testing, and Protection, Vol.13A, ASM Handbook, ASM International, 2003, p210-213.

9. G. Song, Recent progress in corrosion and protection of magnesium alloys. Advanced Engineering Materials 7 (2005) 563-586.

10. M. D.Bharadwaj, A.K.Sachdev, M.Verbrugge, Sacrificial Coating for Magnesium Components, US patent, US7713618B2, May 11, 2010.

11. T. Ohzuku, Y. Iwakoshi and K. Sawai, Formation of Lithium, Graphite Intercalation Compounds in Nonaqueous Electrolytes and Their Application as a Negative Electrode for a Lithium Ion (Shuttlecock) Cell, J. Electrochem. Soc. 140(1993)2490-2498.

12. M. W. Verbrugge and B. J. Koch, Modeling Lithium Intercalation of Single Fiber Carbon Microelectrodes, J. Electrochem. Soc. 143 (1996) 600-608.

13. Y. Chen, B. Luan, G.-L. Song, Q. Yang, D. Kingston, F. Bensebaa, An investigation of new barium phosphate chemical conversion coating on AZ31 magnesium alloy, Surface \& Coating Technology 210(2012)156-165.

14. S. Yagi, A. Sengoku, K. Kubota, E. Matsubara, Surface modification of ACM522 manesium alloy by plasma electrolytic oxidation in phosphate electrolyte, Corrosion Science 57(2012)74-80.

15. R. L. Sacci, L. A. Adamczyk, G. M. Veith, N. J. Dudney, Dry synthesis of lithium intercalated graphite powder and fiber, J. Electrochem. Soc. 161(4) (2014) A614-A619. 
16. G. Liu, H. Zheng, V. S. Battaglia, "Fabrication procedure for LiMn2O4/Graphite-based Lithium-ion Rechargeable Pouch Cells", http://www.osti.gov/bridge/servlets/purl/90951873kn0P/909518.pdf.

17. G.-L. Song, Z. Shi, Corrosion mechanism and evaluation of anodized magnesium alloys, Corrosion Science 85(2014)126-140

\section{Figure captions}

Fig. 1. OCPs of bare and coated $\mathrm{Mg}$ in saturated $\mathrm{Mg}(\mathrm{OH})_{2}$ solution.

Fig. 2. BSE images of cross-sections of corrosion damage morphologies of (a) bare $\mathrm{Mg}$, (b) $\mathrm{C}$ coated $\mathrm{Mg}$, (c) $\mathrm{CLi}_{6}$ coated $\mathrm{Mg}$ and (d) $\mathrm{PO}_{3}$ coated (metaphosphated) $\mathrm{Mg}$ after 24 hour immersion in saturated $\mathrm{Mg}(\mathrm{OH})_{2}$

Fig. 3. BSE image of the cross-section and element distribution of metaphosphated $\mathrm{Mg}$ before immersion in saturated $\mathrm{Mg}(\mathrm{OH})_{2}$.

Fig. 4. BSE image of the cross-section and element distribution of metaphosphated $\mathrm{Mg}$ after 24 hour immersion in saturated $\mathrm{Mg}(\mathrm{OH})_{2}$.

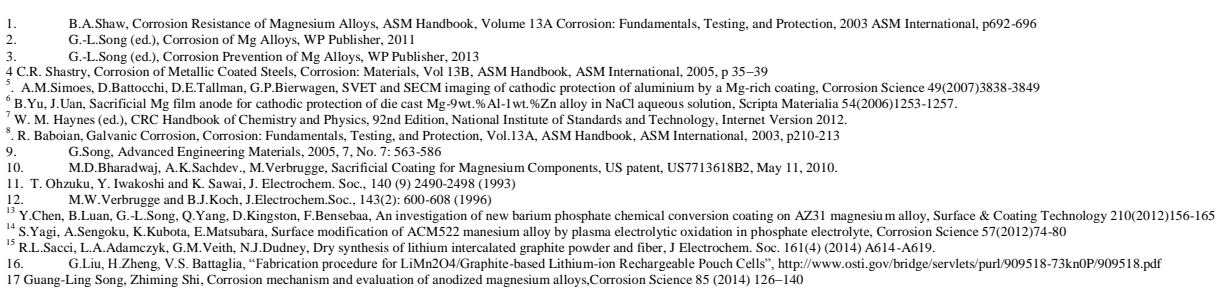




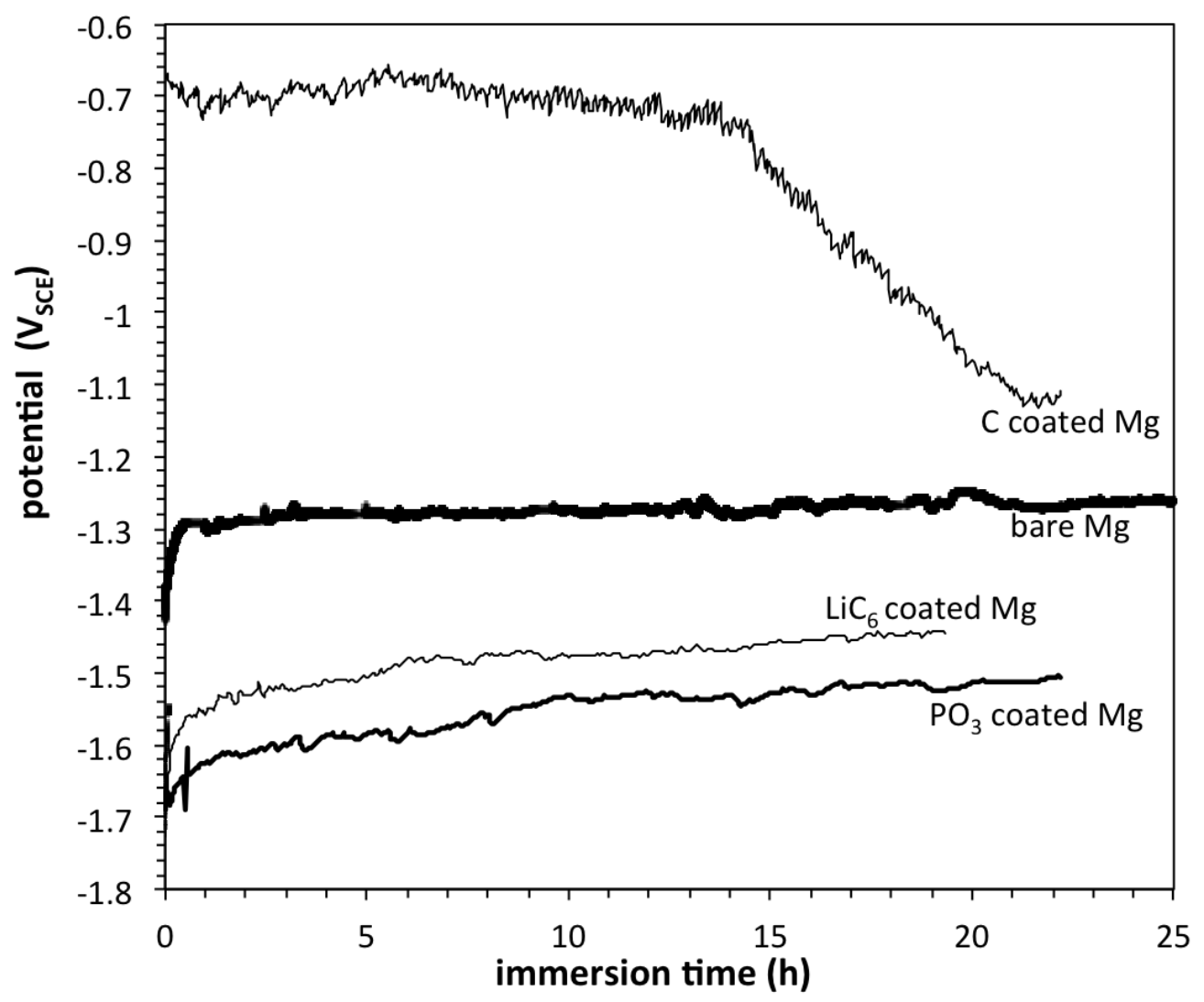

Fig. 1. OCPs of bare and coated $\mathrm{Mg}$ in saturated $\mathrm{Mg}(\mathrm{OH})_{2}$ solution. 

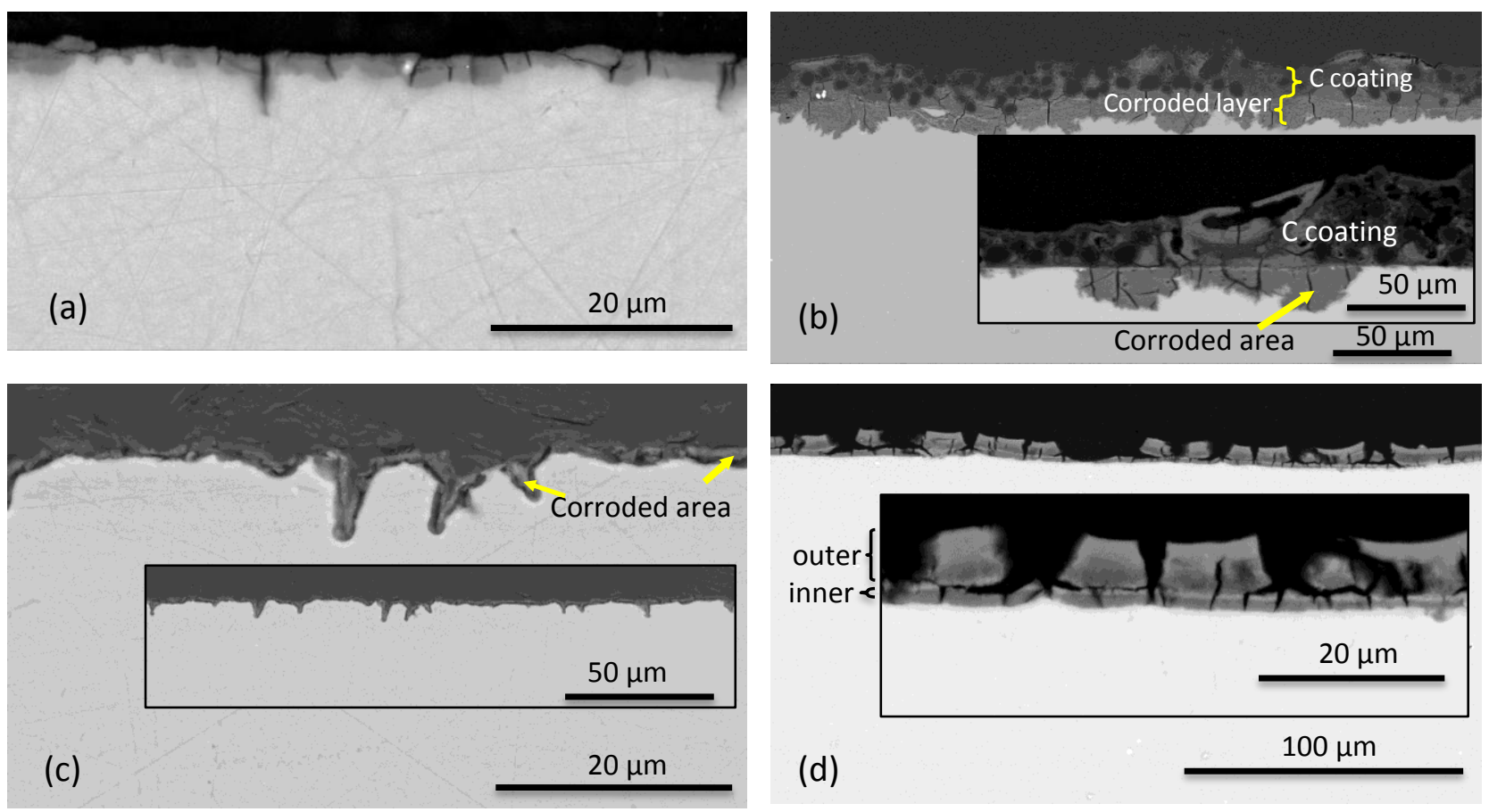

Fig. 2. BSE images of cross-sections of corrosion damage morphologies of (a) bare $\mathrm{Mg}$, (b) $\mathrm{C}$ coated $\mathrm{Mg}$, (c) $\mathrm{CLi}_{6}$ coated $\mathrm{Mg}$ and (d) $\mathrm{PO}_{3}$ coated (metaphosphated) Mg after 24 hour immersion in saturated $\mathrm{Mg}(\mathrm{OH})_{2}$ 


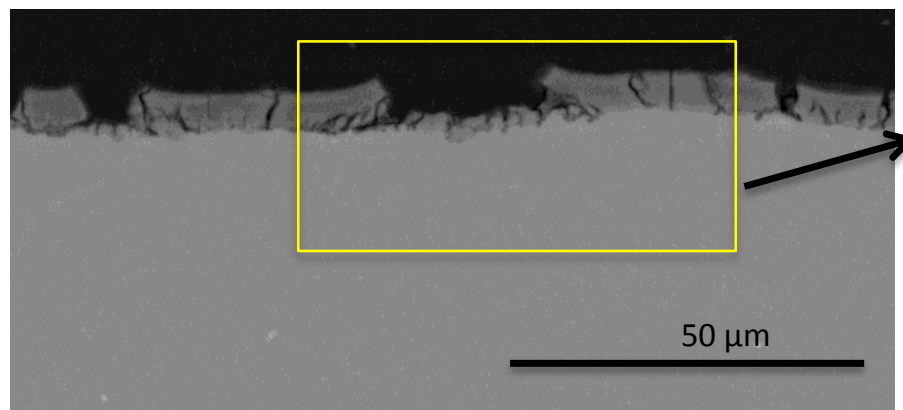

(a)

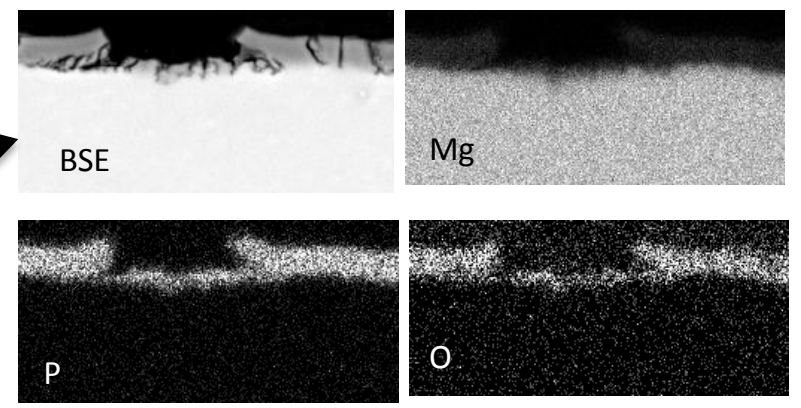

(b)

Fig. 3. BSE image of the cross-section and element distribution of metaphosphated $\mathrm{Mg}$ before immersion in saturated $\mathrm{Mg}(\mathrm{OH})_{2}$. 

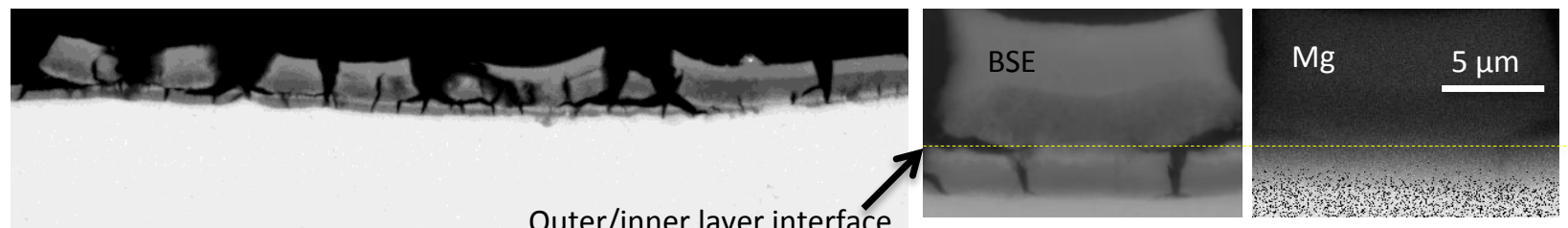

Outer/inner layer interface

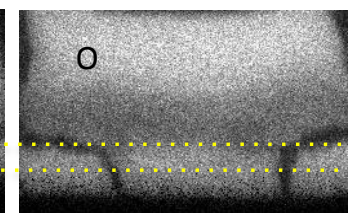

(a) (b)

Fig. 4. BSE image of the cross-section and element distribution of metaphosphated Mg after 24 hour immersion in saturated $\mathrm{Mg}(\mathrm{OH})_{2}$ 